\title{
Transnational civil society and informal public spheres in the nuclear non- proliferation regime
}

\author{
David J Norman ${ }^{1}$ \\ This is an Author Accepted Manuscript (AAM) for the European Journal of International Relations (accepted \\ $30 / 3 / 2018)$
}

Please cite from https://doi.org/10.1177/1354066118774836

Scholars charting the emergence of transnational public spheres often focus on the socio-spatial sites that are generated by Civil Society Organisations (CSOs) in their interactions with the institutions of global governance. These sites can either reflect strong public spheres within the formal decision-making structures of international regimes, or segmented and general public spheres on their periphery. In practice, they all suffer key democratic deficiencies in either the ability to communicatively generate public opinion or achieve collective will-formation. I argue that if CSOs can successfully weave together both general and segmented public spheres on the periphery of international regimes, their individual democratic deficiencies could be addressed. To demonstrate evidence of these interconnected 'informal public spheres' I turn to the nuclear non-proliferation regime where public deliberation has been largely invisible and ineffectual within the formal decision-making structures of the nuclear Non-Proliferation Treaty (NPT). The emergence of a new CSO-led 'humanitarian initiative' on the periphery of the regime comprising multi-stakeholder initiatives in conjunction with CSO social forums, reflects the interconnection of segmented and general public spheres. This innovative initiative has effectively enhanced transnational public debate on disarmament, whilst gaining crucial political traction within the regime.

Key words: Transnational Civil Society, Public Spheres, Democratic Deficit, Critical Theory, Global Governance, Nuclear Proliferation

\section{Introduction}

Transnational Civil Society Organisations (CSOs) have been enjoying a renaissance of late as a key ingredient in the 'democratic soup' (Dryzek, 2011) of global governance. Despite the heterogeneous and often asymmetrical composition of these organisations and their networks, their proliferation as consultants, participants, and observers in global governance reflects, for many, an important advancement in 'democratic polycentrism' (Archibugi et al., 2012). Furthermore, the ability of CSOs to act as transmission belts between local stakeholders and global rule-makers has given rise to new thinking on their role in establishing transnational public spheres; institutionalised arenas of discursive interaction that connect transnational public issues to global policy-making (Bohman, 2010; Brem-Wilson, 2017; Eckersley, 2007; Fraser, 2014; Germain, 2010; Nanz and Steffek, 2004; Samhat and Payne, 2003). CSOs increasingly operate within, and across, a multitude of transnational networks. The complex configuration of these networks, and their relationship to political authority, reflects different levels in the institutionalisation of transnational public debate.

\footnotetext{
${ }^{1}$ Coral Bell School of Asia Pacific Affairs, Australian National University. David.j.norman@anu.edu.au
} 
Eriksen $(2005,2009)$ suggests a useful threefold typology of strong, segmented and general public spheres that relates to the physical distance between the political centre and the periphery of global politics. Strong public spheres form when citizens are granted access to deliberate alongside state actors within institutionalised bodies of executive decision-making (Eriksen 2005; 349). There is a wealth of democratic scholarship focusing on the role of CSOs within these formal deliberative spaces (Brem-Wilson, 2017; Dany, 2008; Eckersley, 2007; Germain, 2010; Kissling, 2013; Steffek, 2010). Additionally, there has been growing interest in the importance of transnational civil society contributing to public spheres outside of formal political decision-making bodies (Conway, 2004; Della Porta and Rucht, 2013; Kurasawa, 2014;). These spaces approximate general public spheres, where public communication is only indirectly able to influence the political system. Eriksen adds a third crucial 'middle ground'; which he calls segmented public spheres. These discursive sites form within the quasi-political spaces of policy-networks and forums where CSOs deliberate with policy-makers in an informal environment (Eriksen 2005: 349; see also Bäckstrand, 2006).

In this article I first briefly assess the democratic possibilities of these three public spheres, adapting Fraser's (2014) democratic criterion of 'normative legitimacy' and 'political efficacy' to assess whether opinion-formation is communicatively generated through an inclusive and deliberative process, and if it is able to exert meaningful influence over political authority. I argue that currently existing strong public spheres are democratically deficient in both the communicative process of opinion-formation, and their collective will-formation. Empirical discussions tend to offer a sober reflection of CSO participation in decision-making as well as the ability to attain meaningful political influence. At the more informal sites of power I argue that both segmented and general public spheres reflect inverse mirror images of each other's strengths and weaknesses. Segmented public spheres have a higher chance of public communication gaining policy traction, yet opinion-formation may be communicatively distorted. General public spheres excel in communicative opinion-formation yet as a site of 'engaged withdrawal' (Kurasawa, 2014: 91) they struggle to convert this power into political influence.

Public sphere scholars recognise the importance of conceptualising the transnational dimension as a structured network of interlacing public spheres (Bohman, 2007; Eriksen, 2009; Fraser, 2014; Couldry, 2014; Risse 2015; Steffek, 2010; Volkmer, 2014), yet few² studies exist examining the interrelationship of these different democratic sites. In this article I examine the particular interconnection between segmented and general public spheres and argue that when CSOs successfully connect the two discursive sites outside of the formal process of political governance, their inverse mirror images combine to democratically strengthen both the opinion-formation, and will-formation, of public debate. I propose to call this particular configuration an informal public sphere that reflects intra-public dialogue on the periphery of international regimes.

In order to demonstrate the feasibility of this particular transnational public sphere, I turn to recent developments in the highly contentious nuclear non-proliferation regime. In recent years CSOs have been granted greater access to contribute to Non-Proliferation Treaty (NPT) discussions via the central decision-

\footnotetext{
2 One notable exception is Stevenson and Dryzek's (2014) deliberative systems approach that conceptualises the different discursive sites as constitutive parts of an overarching system of governance.
} 
making bodies of the Review Conferences (RevCons) and Preparatory Committees (PrepComs). Despite increased access, these strong public spheres remain largely exclusive and unresponsive to overwhelming CSO demands for meaningful dialogue on the abolition of nuclear weapons. Fuelled by these frustrations, prominent disarmament CSOs launched a new International Campaign to Abolish Nuclear Weapons (ICAN) in 2007, and sought alternative platforms to pursue a more open and public dialogue to bring 'democracy to disarmament' (Duarte, 2009). In 2013, ICAN helped co-organise a new public-focused 'Humanitarian Impact of Nuclear Weapons' (HINW) initiative comprised of three unique consultative conferences attended by the majority of NPT signatory states. These 'segmented public spheres' were supplemented by two separate ICAN Civil Society Forums (ICSF) that functioned as crucial 'general public spheres' feeding into the main HINW conferences. The interconnectivity of these sites arguably reflects an informal public sphere on the periphery of the non-proliferation regime. Using a combination of interviews, commentaries and policy documents from both the conferences and forums, I show that this particular public sphere reflected a more communicatively enhanced environment for public opinionformation, whilst at the same time underpinning the unprecedented 2017 adoption of a Nuclear Weapons Ban Treaty. The emergence of the Humanitarian Initiative demonstrates how informal public spheres can enhance both the normative legitimacy, and political efficacy, of public opinion outside of the formal centres of governance.

\section{Transnational public spheres and the role of civil society}

The concept of a public sphere refers to a 'sociospatial site of public interaction' (Castells, 2008: 79) where citizens rationally deliberate over social and political issues, generating streams of communication that "coalesce into bundles of topically specified public opinions" (Habermas, 1996: 360). The public sphere is not merely a site of opinion-formation, but also one of collective will-formation, where public opinion ${ }^{2}$ is mobilised to influence the sites of political authority. The dual nature of this discursive site has a powerful normative and democratic role; a truly autonomous and pluralist communicative environment that functions as an interface between society and the state allows for the effective legitimisation and delegitimisation of political orders (Eriksen, 2009: 150). Thus the public sphere should be seen as a 'criticalconceptual resource' (Fraser, 2014: 9) that allows scholars to assess the ability for citizens to exercise meaningful influence over political authority (Crack, 2007: 344).

In the field of International Relations, the increasingly transnational nature of public communication networks has led to new interest in the democratic possibilities of 'transnational' public spheres (Bohman, 2010; Eckersley, 2007; Fraser, 2014; Germain, 2010; Nanz and Steffek, 2004; Samhat and Payne, 2003). Aware of the problems of 'scaling-up' the concept without a unified global public, scholars instead point to the amorphous 'discourse constellations' (Peters et al., 2005: 143; see also Hauser, 1998) that flow across borders through a patchwork of interlacing national publics. As such, transnational public spheres constitute 'multiple networked publics' (Bohman, 2007; Couldry, 2014; Steffek, 2010; Volkmer, 2014) where national and transnational communication flows converge around common frames of reference (Abrahamsen and Williams, 2014; Gilman-Opalsky, 2008; Porter, 2014; Risse, 2015; Trenz, 2008). This

2 Habermas' notion of public opinion is not the aggregation of individual interests but the result of a general will based on the argumentative search for the common good (McCarthy, 1992: 54) 
convergence is often temporary and issue specific, waxing and waning according to the pertinence of shared public issues.

The social infrastructure of these public spheres is arguably constituted by transnational networks of civil society organisations (CSOs) who approximate 'surrogate publics' (Bohman, 2010: 435) when they represent those individuals seeking to negotiate and struggle for a social contract with transnational sites of authority (Kaldor, 2007: 299; Young, 2002: 173). In the absence of formal democratic institutions at the global level, public spheres represent alternative democratic spaces when CSOs can effectively mobilise public opinion across borders and challenge political decisions at the international level (Bohman 2007: 65). Habermas' (1991 [1962]) early work on public sphere theory tended to focus on civil society more as a conceptual space, thus overlooking the roles and identities of those actors and social movements that were crucial to making and re-making the public sphere (Benhabib, 1992; Calhoun, 1992). By focusing on the 18th century 'coffee houses' of the bourgeois public sphere, Habermas missed the important emergence of subaltern groups to push and expand the boundaries of what constituted public space. These movements were crucial in re-orientating the agenda of public discourse, introducing new social and political issues, and mobilising public opinion to influence the sites of political authority (Calhoun, 1992; Fraser, 1992). Organised civil society therefore has a 'dual track' role in establishing the discursive sites of opinion-formation on shared public issues, as well as will-formation to connect public opinion to formal political agendas (Cohen and Arato, 1994: 519-32).

At the transnational level, CSOs coordinate across complex networks ranging from ad-hoc and informal transnational social movements (TSMs), to more formalised and professional transnational advocacy networks (TANs). The different configurations of these networks and the discursive environments they establish in relation to political authority, reflect different levels in the institutionalisation of transnational public debate. Eriksen $(2005,2009)$ discusses a threefold typology of transnational public spheres; strong, segmented and general that relate to the physical distance between the periphery and political centre. Mapping the role of CSOs as the social infrastructure of these different public spheres, can help us to understand the roles they play in relation to the opinion-formation and will-formation of public communication.

Strong public spheres exist when public communication is connected to the legal and regulatory architecture of global politics. This includes the plethora of formal conferences, committees, forums, panels, summits and tribunals where deliberation takes place over treaties and conventions of international law and order (Brunkhorst, 2005; Eriksen, 2009). These sites reflect strong public spheres when citizens are able to deliberate with those policy-makers who are authorised to make legally or politically binding decisions. CSOs have gained increasing access to the central forums of international regimes, for example at the Review Conference of the nuclear Non-Proliferation Treaty (NPT), the UN Framework Convention on Climate Change (UNFCCC), and the Ministerial Conferences of the World Trade Organisation (WTO). These 'invited spaces' (Cornwall 2002) can also include formally established CSO sideevents within intergovernmental forums, providing that deliberation is re-connected to the formal policymaking process. Segmented public spheres form within the discursive spaces of informal 'policy networks' that bring together citizens with policy-makers in coordination around common public issue areas (Eriksen, 2005: 349). These sites can include consultative multi-stakeholder initiatives such as the 
European Migration Forum (EMF), the World Economic Forum (WEF) and the World Summit on the Information Society (WSIS). They reflect 'informal empowered spaces' (Stevenson and Dryzek, 2014), often populated by more professionally ${ }^{3}$ orientated CSOs and epistemic communities where 'bureaucrats, experts and organised interests' (Eriksen 2005: 352) often intersect. General public spheres exist at the other end of the spectrum; public forms of communication that are only marginally connected to political mechanisms of governance. As such, they form through the deliberative internal dialogue of transnational CSOs in 'created spaces' (Cornwall 2002) such as international social forums, counter-summits and even transnational protests ${ }^{4}$. Examples include the World Social Forum, Nyelini Food Sovereignty Forum, Klimaforum09 and the G20 Counter-Summit. They can function as 'counter-publics' (Fraser 1992) challenging established rules and norms of governance, but can also include supportive dialogue with businesses ${ }^{5}$ in forums unconnected to authorised political decision-making (Smith 2011; Stevenson and Dryzek 2014). General public spheres therefore represent a form of 'engaged withdrawal' (Kurasawa, 2014: 91) from the formal centres of power, yet this is not to say they are weak publics; they are woven into the body politic as a mechanism for 'cultural production and change' (Peters et al., 2005: 141).

Public sphere theory is of course about more than charting the existence of these discursive spaces; it was developed to critically interrogate the democratic content and structure of those communication flows (Fraser, 2014). As such, democratic theorists highlight how the internal authenticity of the process of opinion-formation must be 'normatively legitimate', whilst at the same time being externally 'politically efficacious' (Fraser, 2014; see also Bohman, 2010; Cohen and Arato, 1994; Stevenson and Dryzek, 2014; Habermas, 1996). The role and identity of transnational civil society, and those actors that constitute it, is fundamental therefore to establishing both a normatively legitimate and political efficacious environment across the different publics. As such, I will firstly examine in more depth the democratic criteria of transnational public spheres and the expectations placed on civil society, before assessing the democratic viability of the different public spheres.

\section{Interrogating the normative legitimacy and political efficacy of transnational public spheres}

In her discussion on the democratic criteria for a normatively legitimate process of opinion-formation, Fraser (2014: 28) suggests that transnational public spheres should ideally meet two key sub-conditions: 'inclusiveness' and 'participatory parity'. The first principle of inclusiveness directly concerns who is authorised to communicate in public discussions. Although scholars often establish the boundaries of the public sphere in reference to an 'all-affected principle' (Näsström, 2011), this proves logistically problematic at the transnational level with multiple demoi. One alternative is to eschew the concept of universal inclusion for a multiperspectival approach; public spheres should be constituted by a socially and economically diverse pool of individuals to capture as much as possible the rich tapestry of competing social and political discourses (Bohman, 2004: 40; Ferree et al., 2002: 308; see also; Risse, 2015; Stevenson

\footnotetext{
3 Professional CSOs often constitute 'policy-outcome-orientated' (Lang 2012: 63-4) organisations, staffed by a professional cadre with technical and administrative expertise in project management, media and advocacy.

${ }^{4}$ Protests often contain deliberative qualities and can be seen as an important component of public deliberation (Smith 2011)

${ }^{5}$ This could include international roundtables comprised of CSOs and prominent business organisations as part of 'experimentalist governance' (Brasset et al 2012).
} 
and Dryzek, 2014). The second sub-condition of 'participatory parity' focuses upon how individuals can fully engage in the process of opinion-formation unimpeded. This requires building public space where all can express and challenge viewpoints, as well as "dismantling institutionalized obstacles that prevent some people from participating on a par with others" (Fraser, 2008: 405) Public sphere theorists often allude to the importance of democratic deliberation as a process of collective decision-making that can radically empower public discussion (Bohman, 2007; Samhat and Payne, 2003; Steffek et al., 2010). A deliberative approach stresses the importance of the participation of all who stand to be affected by a decision, where inequalities amongst interlocutors should be "unbracketed" (Fraser, 1992: 120) to reveal distortions in parity, with new mechanisms developed to compensate. Deliberation is thus designed to minimise strategic communication and enhance the possibility of persuasion by the 'force of the better argument' (Habermas, 1996).

How can CSOs improve both the inclusiveness and participatory parity of transnational public spheres? An inclusive public sphere that is "lively, diverse and innovative" (Calhoun, 2011: 321) is firstly dependent upon the ability for CSOs to accurately represent heterogeneous grievance claims within, and across, national publics. These organisations effectively act as 'self-appointed representatives' for a variety of domestic constituencies; their democratic credentials can be measured by how far they provide political 'voice' for those individuals and communities "where electoral constituencies fail to coincide with those affected by collective decisions" (Montanaro, 2012: 1094; see also Saward, 2008). Secondly, CSOs are not simply an assemblage of 'black boxes' that interact independently of each other. They are often enmeshed within complex transnational networks that are riven with competing interests across asymmetrical resource bases. It is important that discursive environments established through these "polycephalous networks" (Olesen, 2005: 427) do not result in a form of "skewed-representation" (Montanaro, 2012: 1105 ) where some organisations are filtered out from these spaces. Where state and CSO representatives meet at the formal sites of deliberation, special arrangements should be made to enhance the inclusion of economically disadvantaged CSOs for a full spectrum of representation (Nanz and Steffek, 2005: 377).

When it comes to ensuring the 'participatory parity' of public spheres through the institutionalisation of democratic deliberation, scholars tend to view civil society as a natural conduit for communicative argumentation (Risse, 2000). Whilst many individuals within CSOs might engage in deliberative practices, the organisations themselves and the networks they inhabit are not necessarily deliberative agents (Brassett and Smith, 2010). CSOs are just as equally the sites of strategic communication, often as a result of increasingly professional actors that inhabit policy-orientated transnational advocacy hubs. Tensions can exist across networks when agenda-setting is dictated by vertical 'insider' organisations at the expense of horizontal 'outsider' organisations (Tarrow 2005). Implementing internal deliberative practices both across and within networks is therefore essential to ensure that the agenda-setting process is communicatively driven whilst diluting the influence of powerful gatekeepers (Della Porta and Rucht, 2013). CSOs that operate within the formal spaces of international regimes also need to be protected from the possible 'centripetal and colonizing' (Kurasawa, 2014: 85) effects of being drawn into political spaces that might dilute communicative practices whilst undermining accountability chains to the periphery. At the same time, these organisations should not merely play the role of observers, but 
deliberate in key meetings in order to subject decision-making to stronger public argumentation rather than typical strategic policy-making (Deitelhoff and Müller, 2005; Nanz and Steffek, 2005; Risse, 2000)

In order for transnational public spheres to be politically efficacious and fulfil the second criteria for democratic authenticity, they must be able to connect CSO-mediated public communication to the transnational sites of political authority. As Habermas (1996) argues, the ability to detect and identify social and political problems through opinion-formation is only the first step, public spheres need to convincingly amplify and thematize these problems in order for them to be "taken up and dealt with by parliamentary complexes" (1996, p359). Fraser (2014: 31) suggests that this should be thought of as the 'translation' sub-criterion for public spheres; being able to convert the communicative power of public opinion into the administrative power of legally binding frameworks. This sub-criterion might be too demanding for practical applicability, however, given the lack of a global parliament. Nash (2014) suggests that a more fruitful alternative might be to think of political efficacy as 'usefulness'; measured by the extent that transnational civil society can meaningfully influence sites of political authority. Nanz and Steffek (2005) similarly argue that political efficacy should be measured by how 'responsive' these sites of political authority are to the demands of transnational civil society. They suggest that low levels exist when the concerns and positions of CSOs are not discussed and medium levels when policy-makers attempt to 'justify' their proposals with reference to CSO concerns. Of course, justification may simply be rhetorical, therefore higher levels can be observed when policy-makers actually 'adjust' their positions and either adopt CSO concerns in part or whole, or bring those concerns onto new political agendas (2005: 376). Responsiveness can be traced by engaging in content analysis comparing CSO written and oral statements with the political output in international organisations, or through participant observation to record when persuasive public discourses are taken up by policy-makers (Dany, 2008; Nanz and Steffek, 2005; Steffek et al., 2010; Stevenson and Dryzek, 2014).

Although these indicators are helpful in assessing the overall democratic authenticity of transnational public spheres, Conway and Singh (2009) argue that we should not uncritically assume that the coconditions of normative legitimacy and political efficacy can be met across different types of public spheres. This is a pertinent point; how 'democratic' are the general, segmented and strong publics present in global politics today? I will now turn to a brief empirical examination of the different public spheres in light of these indicators, and demonstrate how that they do indeed reflect different democratic strengths and weaknesses.

\section{Transnational public spheres in practice: Measuring democratic authenticity}

In recent years CSOs have gained increasing access to intergovernmental conferences, summits, committees and conventions; creating strong public spheres at the very centre of international regimes. CSOs are increasingly able to present documents, deliberate on drafts, and offer statements throughout the formal negotiations over new legislation and regulative frameworks (Brem-Wilson, 2017; Orsini and Compagnon, 2013; Stevenson and Dryzek, 2014). Despite the increased presence of CSOs within these spaces, evidence suggests that strong public spheres can be deeply exclusive and suffer participatory deficits. CSOs are very much vulnerable to political selectivity through external accreditation policies; those organisations that do not conform to certain expectations can find themselves excluded from open 
sessions and their accreditation revoked (Fisher, 2010; Orsini and Compagnon, 2013; Stevenson and Dryzek, 2012). Policy-makers still have a tendency to expect CSOs to passively observe intergovernmental negotiations and report back outcomes to domestic publics, rather than actively shape the agenda. As such they can be excluded from genuine deliberation and shut out of discussions when policy-makers feel the need for 'delicate horse trading' (Böhmelt et al., 2014; Carroll, 2002: 21; see also; Dany, 2008; Eckersley, 2007; Kissling, 2013). Steffek et al (2007) edited a collection examining CSO deliberations with policy-makers across a range of intergovernmental fora and found 'disconcerting' examples of marginalisation, paternalism, loss of independence and even co-option from close collaboration with governments and international organisations. Similar conclusions have been reached by authors assessing CSO participation and inclusion across a variety of international regimes including: finance and trade (Hopewell, 2017; Kapoor, 2005; Scholte 2012;); Information and Communications Technology (ICT) governance (Cogburn 2017; Carr 2015; Dany 2012); the environment (Eckersley 2007; Fisher 2010; Bäckstrand and Kuyper 2017); and security (Atwood 2006; Kissling 2013; Wisotzki 2009). Although there is evidence to suggest that CSOs can achieve 'moderate to high levels' (Betsill and Correll, 2008) of influence and thus political efficacy during formal negotiations, there is little evidence to suggest that this has been achieved as a direct consequence of specific CSO texts, and statements deployed within negotiations. Indeed, meaningful influence is more likely a consequence of CSO frame-shaping over a longer time-span through a multitude of channels (Humphreys, 2008). In short, strong public spheres are often democratically deficient due to both distortions in the sites of deliberation, and an inability to enact collective will-formation. It is therefore understandable why a number of scholars advocate developing new institutional and legal formats, such as global parliamentary assemblies, to try and mitigate global democratic deficits (Archibugi, 2008; Falk and Strauss, 2011; Tännsjö, 2008).

What of the democratic composition of those public spheres that exist outside of the formal spaces of executive decision-making? The political efficacy of segmented public spheres, often comprised of powerful TANs coordinating with policy-makers in consultative environments, is perhaps easier to trace. Key human security initiatives such as the ban treaties on Landmines (1997) and Cluster Munitions (2008), and the UN Programme of Action on Small Arms (2001), were underpinned by consultative multistakeholder forums outside of formal negotiating channels (Atwood 2006; Price, 1998; Velin, 1997). Furthermore, much of the success can attributed to the campaign work of powerful TANs to help frame the debate and lobby governments for multilateral dialogue. The agenda-setting power of CSOs is often maximised outside of those channels where direct dialogue with policy-makers, the public, scientific bodies and the media can create powerful centralised campaign narratives to push debate into the formal realm of politics (Borrie et al., 2011; Carroll, 2002; Lang, 2012). Multi-stakeholder forums are often more deliberative due to their broader consultative and non-negotiating setting ${ }^{6}$. However, more often than not, deliberation reflects an elite form of communication where 'experts and the well-educated' meet to coordinate action (Eriksen, 2005: 352; see also; Lang, 2012). There is evidence to suggest that when multistakeholder initiatives are established by participants with a strong alignment of interests, CSO dialogue is driven by large professional organisations with a lack of grassroots representation (Bäckstrand, 2006: 487-88). It was noticeable for instance that the multi-stakeholder conferences preceding the Mine Ban Treaty were overwhelmingly dominated by Northern-based CSOs (English 1998: 128). The emergence of powerful 'advocacy hubs' reflect an increasing gap between professional bureaucratic organisations and

\footnotetext{
${ }^{6}$ Although as Brown (2010) highlights, even forums with deliberative safeguards can still be subject to manipulation from powerful state actors.
} 
those with stronger ties to public grievance claims (Ferree et al., 2002: 300 see also; Carpenter, 2014; Fernandes, 2005; Pieck 2013). Ultimately, despite the rhetoric from CSOs within TANs on being able to negotiate both invited and claimed spaces, in practice many of these organisations struggle to navigate both identities (Yanacopulos, 2015: 30).

General public spheres that also exist outside of formal channels, can be seen as the inverse of segmented public spheres. Those transnational forums, events and conferences that are purposively unconnected to policy-making allows CSOs to avoid being drawn into the 'institutional logics of governance' (Kurasawa, 2014: 86) and can thus potentially invigorate 'the quality of public space' (Stevenson and Dryzek, 2014: 33). Transnational Social Movements for example, often connect through physical and digital forums that prioritise marginalised voices in public deliberation (Della Porta and Rucht, 2013). Similarly, the recent explosion of Online Campaigning Organisations (OCOs) integrate virtual community building tools into their organisational frameworks to further de-territorialise public forms of communication (Yanacopulos, 2015). The World Social Forum and its regional deliberative spin-offs, utilise innovative 'open space' (Rucht, 2012) dialogic techniques that improve both the inclusiveness, and participatory parity, of opinionformation. Despite exhibiting higher levels of normative legitimacy than the other more policy-orientated public spheres, unfortunately these spaces often lack the ability to translate public communication into political will-formation (Conway and Singh, 2009; Patomäki and Teivainen, 2004). The political efficacy of public opinion within these transnational spaces is exceptionally difficult to trace without any meaningful connection to policy-makers.

On the periphery of international regimes, segmented public spheres can generate significant political traction but often at the expense of inclusive dialogue and public agenda setting, whilst general publics can generate radically inclusive forms of public communication that are all too often isolated from political influence. If we accept that transnational public spheres constitute a 'field of discursive connections' (Calhoun, 1992: 37) then there is scope to think about the interconnection of these general and segmented public spheres. Given the inverse democratic strengths and weaknesses of the two sites, CSO networks that can successfully weave the two together might be able to improve both the opinion-formation, and collective will-formation, of transnational public communication. I propose to think about this interconnectivity as constituting an informal public sphere within international regimes where these discursive sites can generate substantial political pressure from a distance, whilst maintaining high levels of normative legitimacy. To investigate this possibility, I turn to an empirical examination of the nuclear non-proliferation regime where CSOs have traditionally struggled to generate opinion-formation and political will-formation within the formal sites underpinning the regime. The creation of CSO-led social forums and connecting multi-stakeholder conferences under the auspices of a new Humanitarian Impact of Nuclear Weapons (HINW) initiative, arguably constitutes such an informal public sphere. I argue that these dialogic spaces have had significant impact on the nuclear Non-Proliferation Treaty (NPT) whilst providing new democratic channels for public debate.

\section{From outside to inside: CSOs and strong public spheres in the nuclear non-proliferation regime}

The global nuclear non-proliferation regime comprises a broad array of international organisations, treaties, initiatives, summits and networks that govern the interconnected issue areas of nonproliferation, disarmament and the peaceful uses of nuclear technology. These 'three pillars' of the regime are reflected in the landmark 1968 nuclear Non-Proliferation Treaty (NPT) with a legally binding framework emphasizing: the non-acquisition of nuclear weapons by current Non-Nuclear 
Weapons states (NNWS); the denial of assistance in acquiring nuclear weapons by the Nuclear Weapons States (NWS) who also agree to eventual disarmament; and guaranteed access to peaceful civilian nuclear technology for all signatories. The NPT thus functions as the 'centrepiece' (Thakur et al., 2008: 5) of the non-proliferation regime, representing a 'grand bargain' struck between the NWS and the NNWS to work together to stop nuclear proliferation whilst moving towards complete disarmament. Whilst the treaty itself constitutes the rules and principles of the regime, it is constantly reviewed and scrutinised at a recurring quinquennial NPT Review Conference (RevCon) preceded by three separate NPT Preparatory Committees (PrepComs) to address substantive and procedural issues relating to the treaty. Historically, discussions during the RevCons and PrepComs have been steered by the NWS to focus on non-proliferation and incremental arms control to ensure strategic stability in an unstable world (Walker 2011). A substantial fracture, however, has emerged between the NWS and NNWS where the latter feel aggrieved at the slow pace of this 'incremental steps ${ }^{\prime 7}$ approach to disarmament. These states argue that they only agreed to lock themselves into a position of nuclear inferiority if the NWS would take their disarmament obligations seriously (Bukovansky et al 2012: 87). At stake is the interpretation of Article VI of the NPT concerning the pursuit of disarmament "in good faith" by the NWS. The NNWS point to the 1995 International Court of Justice's ruling on the illegality of nuclear weapons, the agreed ' 13 practical steps' at the 2000 RevCon and the agreed Action Plan of the 2010 RevCon, to reiterate that a concrete road-map for the elimination of nuclear weapons should be on the RevCon agenda. This position is often vocalised by the Non-Aligned Movement (NAM) of states and the New Agenda Coalition (NAC) who argue that elimination is entirely consistent with the promises underpinning Article VI (NPT 2015a; NPT 2015b). The frustration of the NNWS is also widely mirrored by those transnational CSOs who attempt to engage with the regime. An overwhelming majority of CSOs have long championed nuclear elimination under article VI, and feel aggrieved not to have a strong vocal presence within the RevCon debates.

CSOs were only first able to participate in the formal deliberations of the NPT at the 1994 PrepCom where they could attend open meetings, submit documentation and brief delegates "on the margins of the Committee's deliberations" (NPT, 1994). Taking advantage of these new spaces, a group of CSOs formed an 'NGO Abolition Caucus' at the 1995 RevCon and presented an 11-point statement on the unconditional abolition of nuclear weapons. Over 200 CSOs then formed Abolition 2000; a decentralised network calling for a Nuclear Weapons Convention (NWC) to be negotiated by the end of the century (Archer 2005). A working group affiliated to the network successfully drafted a model NWC that, although submitted to the UN in 1997 by Costa Rica, received little meaningful uptake by states in the following 2000 RevCon.

Despite amassing over two thousand member-organisations, Abolition 2000 failed to achieve its timetabled NWC. However, lessons learnt from the successful International Campaign to Ban Landmines (ICBL) underpinning the 1997 Mine Ban Treaty gave impetus to the rise of a new centralised campaign advocating nuclear disarmament. The International Campaign to Abolish Nuclear Weapons (ICAN) was launched at the 2007 PrepCom, underpinned by the Nobel-prize-winning International Physicians for the Prevention of Nuclear War (IPPNW), with the ambition of reframing the discourse on nuclear weapons and promoting treaty negotiations with like-minded states. ICAN's launch

\footnotetext{
${ }^{7}$ This 'building blocks' approach centres on strategic arms reductions, confidence building, and nuclear security
} 
coincided with new regulations at the 2007 PrepCom granting CSOs previously unheard-of access to all debates and thematic discussions with government delegates (Kissling, 2013: 58; Nordstrom, 2007: 1-2). At the same time, the original $1997 \mathrm{draft}$ NWC was subsequently updated and badged under the ICAN umbrella to push for concrete elimination talks. At the 2010 RevCon, 144 states voiced strong support for kick-starting discussions on an NWC, yet despite this 'massive jump in statements' (Johnson 2010) the final consensus document made only the vaguest of passing reference to the convention (NPT, 2010b, 2010a). IPPNW bemoaned that the NWS continued to 'resist inclusion of reference to the convention' despite overwhelming calls from states and civil society (Loretz 2010). One of ICAN's campaign directors lamented the 'tired old mantra of arms control' (ICAN 2010: 24) whilst the campaign itself put out a report expressing disappointment in the current system of 'nuclear apartheid' (ICAN 2010: 1) where different standards seem to apply to different states within the NPT.

Although CSO access at the RevCons to brief delegates and 'attend deliberations' (Duarte, 2009) signifies the emergence of a strong public sphere at the heart of the regime, the normative legitimacy of these deliberative spaces is problematic. One of the obstacles to the production of opinionformation within the PrepCom and RevCon process, is that CSOs often remain isolated from the sites of meaningful deliberation. Kissling's (2013) analysis of the 2005 RevCon suggests that key deliberative discussions were dominated by a small core of powerful delegates who engaged in strategic bargaining behind closed doors (2013: 174). Although three of ICAN's steering group organisations made official statements at the 2010 RevCon, CSOs were not invited to join the new subsidiary bodies that had been established under each of the three main committees. ICAN's current executive director argued that a number of key revisions to draft documents were made during these closed deliberative sessions which took them outside of the realm of public scrutiny (Finn, 2010). Similarly, only 16-20 delegates in conjunction with the RevCon president deliberated over the content of the final 2010 consensus behind closed doors (Johnson, 2010). There have been a few reform attempts to date; the Chair's draft recommendation at the 2009 PrepCom called for enhanced CSO participation, however this was heavily watered down in subsequent drafts (NPT, 2009a, 2009b). Ultimately, the key deliberative spaces within the NPT lack the meaningful participation of CSOs who remain very much 'relegated to the hallways' (Kissling, 2013: 70). Similarly, the failure of CSOs under the umbrella of both Abolition 2000 and ICAN to generate 'meaningful' debate amongst government delegates up until the 2010 RevCon, demonstrates a substantial deficit in the political efficacy of transnational public opinion.

Given the frustration felt by both the NNWS and CSOs at the culmination of the 2010 RevCon, ICAN joined a large number of states in exploring other avenues through which to discuss nuclear abolition. The RevCon's perceived elitism and closed networks led to calls from various organisations within ICAN for new thinking on how to open up the NPT to broader public communication and bring 'democracy to disarmament' (Duarte, 2009; Wright, 2010: 3). The campaign began internal deliberations on how to 'think outside the bomb' (ICAN 2010: 39) with regards to supporting the majority of NNWS in broadening the disarmament debate. In 2013 the opportunity arose to coorganise a set of consultative conferences known as the Humanitarian Impact on Nuclear Weapons (HINW) Initiative

\section{From inside to outside: ICAN and the humanitarian initiative}


At the end of the 2010 RevCon, the International Committee of the Red Cross (ICRC) managed to successfully convince Switzerland, Austria and Norway to introduce a sentence in the consensus document expressing deep concern at the 'catastrophic humanitarian consequences' of nuclear detonation (Sauer, 2015: 7-8). As a result, the ICRC in conjunction with ICAN began to heavily promote a humanitarian shift in nuclear disarmament with two key arguments, first; that the use of nuclear weapons would have such dire consequences that to use them would constitute omnicidal destruction, thus breaching all humanitarian principles. Second; in the result of a nuclear detonation, no organisation or state could effectively respond with adequate humanitarian assistance to save lives (Løvold et al., 2013: 147). This broader human security approach connecting environmental, health and humanitarian law, shifts the focus away from the strategic narratives of nuclear deterrence and back to the public opposition to nuclear weapons (Løvold et al., 2013: 146). The campaign undertook a two-prong approach that focused on pushing the humanitarian line with government ministries and policy-makers, whilst 'generating a groundswell of public support' (Wright, 2007) to expand the movement and consolidate pressure in support of their goals (Løvold et al., 2013: 147-149). Crucially, ICAN campaigners recognised that promoting a better understanding of the catastrophic humanitarian consequences of nuclear weapons could help to build public support towards a process to ban nuclear weapons (ICAN 2012). Concurrently a number of frustrated NNWS became interested in this humanitarian narrative and the possibility of galvanising a new perspective on disarmament. At the 2012 PrepCom, the Norwegian delegation delivered a statement inviting all states and CSOs to an informal conference on the catastrophic humanitarian consequences of nuclear engagement.

Norway hosted what was to become the first of three key HINW multi-stakeholder conferences held in Oslo (2013), Narayit (2014) and Vienna (2014) with ICAN as co-organisers. These conferences reflect the formation of segmented public spheres; non-negotiating, consultative and informal in nature, connecting CSOs to governmental delegates. Crucially, ICAN hosted its own ICAN Civil Society Forum (ICSF) in the days prior to both the Oslo and Vienna conferences. These forums consolidated discussion amongst ICAN organisations and activists about the upcoming HINW conferences in an open environment without political influence. As a result, the ICSFs should be seen as general public spheres; public communication that coalesces around common reference points but disconnected from policy-makers. This article will now turn to an examination of how the Humanitarian Initiative 2013-2014 functioned as an informal public sphere; a politically influential set of discourses emerging from the interconnection of segmented and general public spheres outside the formal channels of the RevCon. I argue that the combination of these deliberative spaces improved both the normative legitimacy, and the political efficacy, of public communication on disarmament; enhancing the democratic legitimacy of the non-proliferation regime.

\section{Informal publics and normative legitimacy: The ICAN civil society forums and HINW conferences}

In order for the humanitarian initiative to function as a credible site of opinion-formation, both the forums and conferences need to be highly inclusive with a broad range of voices of interests. It is worth therefore briefly assessing the composition of ICAN as the key transnational advocacy network functioning as the social infrastructure of these spaces. The campaign is comprised of 440 CSOs in over 100 countries that aims to strike a balance between grassroots driven organisations and professional 
advocacy organisations. This is reflected within the ten organisations ${ }^{8}$ that make up the international steering committee with half drawn from key grassroots organisations within Abolition 2000 and the other half drawn from former professional advocacy organisations of the ICBL. The latter organisations helped the campaign to mirror aspects of the ICBL with a tripartite structure of partner organisations, an international steering committee, and an independent secretariat (Interview, 2016c). At the same the campaign wanted to develop an intentionally 'flexible and nimble' (ICAN 2012) administrative infrastructure with important channels for public feedback and local consultation with grassroots organisations. Furthermore, the campaign comprises a diverse mix of humanitarian, environmental, and development organisations, and actively prioritises links with individuals in the Global South to improve representation (Interview, 2015b, 2016c). In Oslo 2013 at the first set of forums and conferences, ICAN presented itself to states as both a 'legitimate global voice' as well as a 'serious governmental partner' (Interview, 2015b).

The ICAN Civil Society forums in Oslo (2013) and Vienna (2014) took place over two days directly preceding the HINW conferences, drawing an unprecedented number of CSOs; the forum in Oslo drew over 500 participants whilst the final forum in Vienna hosted over 620 participants from 100 organisations in over 70 countries. The steering group organisations predominantly responsible for coordinating the forums prioritised diverse geographical representation and youth engagement. In a surprising move they ceded much of the control to younger, less experienced campaigners rather than traditional advocacy specialists and were impressed with the diversity and vibrancy of a post-cold war generation of young activists (Interview, 2015a). Although the majority of participants were from ICAN-affiliated organisations, the open-door nature of the forums brought forth parliamentarians, lawyers, scientists and religious leaders to engage with the campaign over disarmament issues.

The inclusive nature of the forums was complemented by a parity of participation amongst its interlocutors. The ICSF introduced a number of innovative discursive formats ranging from open workshops, interactive panel discussions, rapid-fire 'lightning speeches', lunchtime breakout sessions, informal meet and greet sessions, a speakers' corner and a marketplace for disseminating information (goodbyenuk.es 2014; Loretz 2013). The forum shared poetry and song, stories from the Hibakusha, Japanese survivors of the atomic bomb, as well as virtual media presentations from celebrities to religious leaders. The informal and open dialogue format reflected a 'laboratory for experimentation' (Smith et al. 2008: 41) typical of a social forum that enabled vibrant outside the box thinking on disarmament (Loretz 2013). On the second day of the forums, open-dialogue shifted to a more thematic and deliberative approach to campaign planning; breakout sessions and a special campaigners' session gave activists from several countries an opportunity to bring their local activist knowledge to the discussions (Loretz 2014). However, as is typical with a social forum, without connecting these innovative discussions to those policy-makers who determine the pathways to disarmament, the political efficacy of public communication generated was severely limited. It was only when ICAN participants introduced these discussions and innovative deliberative mechanisms

\footnotetext{
8 Including Acronym Institute for Disarmament Diplomacy, African Council of Religious Leaders, Religions for Peace, Article 36, International Physicians for the Prevention of Nuclear War, Latin America Human Security Network, Norwegian People's Aid, PAX, Peace Boat, Swedish Physicians against Nuclear Weapons, Women's International League for Peace and Freedom.
} 
into the HINW conferences that a genuine 'campaign community' with like-minded states could take root (Interview, 2015a, 2016a).

The subsequent HINW conferences in Olso (2013), Narayit (2014) and Vienna (2014) were hailed as unique in their equitable balance between CSOs and government delegates. At the first conference for example, there were 127 official CSO representatives that mirrored the 127 states present $^{9}$. This is a dramatic departure from the PrepComs and RevCons in that the conference aimed specifically to engage with "audiences and participants not usually included in high-level discussions on nuclear weapons" (Williams et al., 2015: 8). ICAN, as official partners, were allotted the majority of CSO slots ${ }^{10}$ ensuring a strong presence; at Oslo representatives from all bar one of the ten steering organisations participated. With limited numbers in comparison to the preceding ICSF, however, the international steering group representatives decided to prioritise youth and regional variance over traditional professional expertise even to the chagrin ${ }^{11}$ of some, to ensure full representation (Interview, 2015c). Although segmented public spheres tend to reflect restricted elite-driven dialogue, this decision by the committee to prioritise broader representation drawn from the prior ICSF helped to maintain a strong transnational public presence in the conferences. In order to ensure public information about the conference could still reach those that weren't able to attend, the Women's International League for Peace and Freedom (WILPF) maintained a media presence and news digest, enhancing transparency and helping to ensure feedback from ICAN to national public spheres. State representation was equally as diverse; the HINW conferences comprised the greatest regional variance of any disarmament conference that has ever taken place (Minor, 2016). This was in large part down to the lower costs to attend, sponsorship programmes for delegates in low income countries, and the perception by many of new opportunities for dialogue outside of the formal RevCon process (Minor, 2016: 3-4). The HINW process was also unique in inviting India and Pakistan to the dialogue, giving delegates a chance to engage with two states that do not attend the RevCons being non-signatories to the NPT. By the time the 2014 Vienna conference was underway, more states (158) were present than had actually attended the 2014 PrepCom.

The substantive content of the conferences was largely generated by ICAN who used the discussions from the ICSF to integrate a facts-based approach on the consequences of nuclear detonation with government delegates. CSOs therefore brought a wealth of new views, experiences and information that government delegates had not heard before in either the PrepComs or RevCons (Gandenberger and Acheson, 2014: 6). Drawing upon the deliberative techniques of the ICSFs, ICAN participants introduced a plethora of testimonials, oral and video presentations to government delegates and had unprecedented access to them whether inside the conference venue or over informal lunches. (Interview, 2016c). This informal approach became the conference's greatest asset; smaller states on the margins could be involved in discussions without being 'locked-out' from closed-door sessions (Interview, 2016b). Indeed, ICAN was immensely successful in facilitating an environment that eschewed strategic bargaining and "encouraged small countries to speak up" (Interview, 2015c). Even

\footnotetext{
9 Although it should be stated that states were often represented by more than one delegate.

10 ICAN were allotted 100 spaces for Oslo, 50 for Nayarit but were, however, unable to select the participants for the final conference in Vienna. Although this resulted in a slight dilution of ICAN's presence in favour of more professional advocacy organisations, the format of the conference still ensured a strong deliberative structure on a relatively even playing field (Interview, 2015c)

${ }^{11}$ As a consequence of prioritising broad representation over expertise, a number of US and UK professional campaigners were reportedly unhappy at missing out (Interview 2015b).
} 
those government delegates that were sceptical of the conferences and the initiative as a whole were forced to justify their positions under higher levels of scrutiny during deliberation (Interview, 2015c). ICAN's executives argued that the campaign brought a more 'dynamic dimension' (Fihn and Acheson 2013) and that the inclusion of a wider set of interlocutors at the conferences, combined with a less restrictive deliberative environment, ensured that participation was on a more even playing field than at either the PrepComs or RevCons.

In terms of the overall normative legitimacy of the Humanitarian Initiative, the ICAN civil society forums helped to create an inclusive communicative space for a broad range of individuals to openly debate the humanitarian impact of nuclear weapons. The vibrancy of these forums were reflected in the decision by the steering committee to prioritise diversity and representation over professional expertise. The substantive and procedural format from the ICSF was then integrated into the HINW conferences, contributing to a more informal deliberative environment between CSOs and government delegates to co-determine consensus on the norms and principles of the initiative.

\section{Informal publics and political efficacy: The Humanitarian Initiative and the Nuclear Weapons Ban} Treaty

A useful method in attempting to measure the political efficacy of the humanitarian initiative is to trace the "responsiveness" (Kissling, 2013; Steffek et al., 2010) of executive policy-makers to public discourses introduced by ICAN organisations within the forums and conferences. This can be done by analysing the overarching themes and tracing their imprint within the political and legal output of the NPT. This section will discuss how the key focus of the Humanitarian Initiative, as both a consciousness-raising exercise in nuclear catastrophe, and a new mechanism to advance nuclear disarmament, has gained significant and unprecedented legal traction. ICAN and its vast network of CSOs that have long campaigned for concrete legal measures towards disarmament have in fact proven extremely successful in influencing the regime.

The immediate outcome of the final HINW conference was a surprise announcement by the Austrian government of a new 'humanitarian pledge' to fill the legal gap for the prohibition and elimination of nuclear weapons. This unexpected decision was met with delight from members of the ICAN steering group who were worried about the possible last-minute dilution of agreed outcomes amongst states (Interview, 2015a, 2015c). The pledge quickly gained momentum and was endorsed by 127 countries committed to the stigmatisation, prohibition and elimination of nuclear weapons, and calling on NPT signatories to fully implement their disarmament obligation under article VI. Crucially, the success of the HINW conferences opened up the door "to move beyond fact-based discussions on the effects of nuclear weapons to the start of treaty negotiations" (ICAN, 2015). The pledge therefore both legitimised and empowered discussion towards a legally binding framework for the elimination of nuclear weapons.

This momentum would not be carried through the 2015 RevCon, however, where despite a full ICAN presence complementing a majority of NNWS in calls for legal negotiations on humanitarian grounds, the final consensus draft only referred to the humanitarian initiative as informative rather than affectual (NPT, 2015c, 2015d). A participant from ICAN's International steering group called the draft RevCon consensus document "anti-democratic and non-transparent" (Acheson 2015a) reflecting the 
views and interests of the NWS with no meaningful discussion on disarmament. The conference was dominated by small group deliberations between main committee chairs which made it "extremely difficult for small delegations from developing countries (and impossible for civil society) to participate" (Acheson 2015b). As such ICAN members found themselves resorting back to direct advocacy within the RevCon with a 'business as usual'(Interview, 2016a) attitude reflecting the same obstacles to deliberation as in the previous RevCons.

Despite this, the NNWS states were undeterred. In December 2015 the UNGA passed two key resolutions that further enhanced the legitimacy and efficacy of the Humanitarian Initiative. Firstly, resolution $70 / 48$ was passed by 139 states ( $83 \%$ of the UNGA) officially endorsing the Humanitarian Pledge. Secondly, resolution 70/33 established an Open-Ended Working Group (OEWG) throughout 2016 to look into the possibilities for concrete measures to achieve multilateral nuclear disarmament. This working group was 'underpinned' (UNGA, 2016: 4) by the humanitarian initiative and was effectively seen as a 'preparatory forum for treaty negotiation' (Interview, 2015c). The final report included a call by a large majority of states and CSOs to convene a UN conference in 2017 to launch negotiations on a Nuclear Weapons Ban Treaty. In October 2016, the First Committee of the United Nations overwhelmingly passed resolution 71/258 (123 states in favour, 38 against, 16 abstentions) to begin negotiations. The resolution established an open UN negotiating conference that took place intermittently over 20 days from March 2017 to July 2017. Throughout the draft legislation states lobbied to introduce the language of the humanitarian initiative (Patton and Pytlak 2017: 3) as the rationale from which to frame the global ethical imperative for a nuclear free world. Finally in July 2017, the final text on the Treaty for the Prohibition of Nuclear Weapons was officially adopted (122 states in favour, 1 against, 1 abstention) with the humanitarian initiative boldly cited within the second paragraph of the preamble.

ICAN may not have been as directly influential in the formal sites of power such as at the RevCons and even the latest UN conference negotiating the text of the treaty, but undoubtedly their work on framing and shaping the Humanitarian Initiative was critical. Indeed, at the organisational meeting for the UN conference on treaty negotiations, the Irish delegation reflected that negotiations would simply not have occurred "without the support and advocacy of our civil society partners" (Pytlak and Acheson, 2017). The development of the Nuclear Weapons Ban Treaty highlights how policy-makers have been fairly 'responsive' (Kissling 2008; Steffek et al 2010) to the demands of civil society by justifying their shift towards elimination based upon the Humanitarian Initiative.

The informal and unofficial nature of the HINW conferences and subsequent prohibition treaty, has however, led to an even greater fracture between the NWS and NNWS. The former have made vocal criticisms of the HINW conferences for "divert[ing] discussion away from practical steps" $(P 5,2013)$ in the RevCon, and that the ban treaty even "endangers the viability of the NPT regime" (NPT 2017). These states tend to see both the conferences and ban treaty as an attempt by dissatisfied NNWS and CSOs to destabilise the NPT through "forum shifting" (Helfer 2004; Orsini 2013); using alternative forums to push a competing agenda on disarmament. However, I would argue that for ICAN and the majority of NNWS, the conferences and ban treaty reflect what Orisni (2013) describes as "forum linking"; creating new spaces designed to complement and enhance RevCons discussion on article VI 
of the NPT. It was the decision of the NWS not to attend the first two HINW conferences or the UN OEWG; ICAN organisations and the NNWS retained a full presence in all the different disarmament fora.

The RevCon is still therefore the deliberative centrepiece of the NPT; the ICAN steering committee and member organisations attend with much passion even in the face of a conference that remains the preserve of realpolitik. Yet the innovative shift by ICAN and a core group of NNWS to co-develop new informal spaces and also to host open-dialogue forums preceding them, demonstrates the important democratic qualities of the Humanitarian Initiative. As an informal public sphere, comprised of interconnected segmented and general public spheres, deliberative debate was inclusive and participatory, whilst at the same time imprinting a more public-orientated political outcome in the form of the Nuclear Weapons Ban treaty.

\section{Concluding thoughts}

Transnational public debate continues to be marginalised within the RevCons and PrepComs at the centre of the non-proliferation regime. This is consistent with criticism of strong public spheres in general, where there are often democratic deficiencies in both the opinion-formation, as well as the political efficacy, of public communication. The rise of multi-stakeholder initiatives and more informal dialogic spaces on the periphery of international regimes offers new avenues for thinking about the important role of segmented public spheres in shaping regimes and channelling public debate through politically collaborative environments. These sites of deliberation, however, are often steered by dominant professional advocacy organisations and policy-makers through elite forms of networking. Finding mechanisms to dilute this form of communication and bolster the normative legitimacy of public communication is key to unlocking more democratic forms of governance. The humanitarian initiative may constitute a unique case where ICAN has benefited from an alignment of interests with those NNWs keen to instigate discussions over a ban treaty. Never-the-less, it demonstrates what can be achieved when public-orientated TANs establish and channel the substantive and procedural content of social forums into multi-stakeholder initiatives. Connecting segmented and general public spheres on the periphery of international regimes can help enhance the function of transnational public spheres as a democratic interface between the rule-makers and the rule-takers of global politics.

\section{Acknowledgements}

I would like to thank Anthony Burke, Lindsay Clark, Julie Gilson, Nicholas J Wheeler, Scott Wisor, Benjamin Zala, and the anonymous reviewers for helpful comments and suggestions on the article.

\section{Funding}

This work was supported by the UK Economic and Social Research Council (Grant Ref: ES/L013320/1) under the project 'Nuclear Ethics and Global Security: Reforming the Nuclear Non-Proliferation Regime' at the University of Birmingham, UK.

\section{Bibliography}


Abrahamsen R and Williams M (2014) Publics, Practices, Power. In: Best J and Gheciu A (eds), The return of the public in global governance, New York: Cambridge University Press, pp. 243-256.

Acheson, R (2015a) 2015 NPT Review Conference outcome is the Humanitarian Pledge NPT News In Review 13:3

Acheson, R (2015b) Editorial: Unsilencing the Majority NPT News in Review 13:14

Archer C (2005) The Creation of the Abolition 2000 Network INESAP Bulletin 25

Archibugi D (2008) The global commonwealth of citizens: toward cosmopolitan democracy. Cambridge Univ Press.

Archibugi D, Koenig-Archibugi M and Marchetti R (eds) (2012) Global democracy: normative and empirical perspectives. Cambridge ; New York: Cambridge University Press.

Atwood D (2006) NGOs and multilateral diplomacy: limits and possibilities. In: Borrie J and Randin VM (eds) Thinking Outside the Box in Multilateral Disarmament and Arms Control Negotiations. UNIDR, pp. 33-49.

Bäckstrand K (2006) Democratizing global environmental governance? Stakeholder democracy after the world summit on sustainable development. European Journal of International Relations 12(4): 467-498.

Bäckstrand K and Kuyper JW (2017) The democratic legitimacy of orchestration: the UNFCCC, non-state actors, and transnational climate governance. Environmental Politics 26(4): 764-788.

Barnaby F (1979) Annual Report from the Stockholm International Peace Research Institute. Bulletin of the Atomic Scientists 35(7): 18-26.

Benhabib S (1992) Models of Public Space: Hannah Arendt, the Liberal Tradition, and Jurgen Habermas. In: Calhoun CJ (ed.), Habermas and the public sphere, MIT press, pp. 73-98.

Betsill MM and Correll E (2008) NGO Diplomacy: The Influence of Nongovernmental Organisations in International Environmental Negotiations. Cambridge, Mass: MIT Press.

Bohman J (2004) Realizing deliberative democracy as a mode of inquiry: Pragmatism, social facts, and normative theory. The Journal of Speculative Philosophy 18(1): 23-43.

Bohman J (2007) Democracy across borders: from Dêmos to Dêmoi. Studies in contemporary German social thought, Cambridge, Mass: MIT Press.

Bohman J (2010) Democratising the global order: from communicative freedom to communicative power. Review of International Studies 36(02): 431.

Böhmelt T, Koubi V and Bernauer T (2014) Civil society participation in global governance: Insights from climate politics: Civil society participation in global governance. European Journal of Political Research 53(1): 18-36. 
Borrie J, Brehm M, Cattaneo S, et al. (2011) Learn, adapt, succeed: potential lessons from the Ottawa and Oslo processes for other disarmament and arms control challenges. In: Acheson R (ed.), Beyond arms control: challenges and choices for nuclear disarmament, New York: Reaching Critical Will, pp. 197-209.

Brassett J and Smith W (2010) Deliberation and global civil society: agency, arena, affect. Review of International Studies 36(02): 413-430.

Brem-Wilson J (2017) La Vía Campesina and the UN Committee on World Food Security: Affected publics and institutional dynamics in the nascent transnational public sphere. Review of International Studies 43(2): 302-329.

Brunkhorst H (2005) Solidarity: from civic friendship to a global legal community. MIT Press.

Bukovansky M, Clark I, Eckersley R, et al. (2012) Special responsibilities: Global problems and American power. Cambridge University Press.

Cabasso J (2010) Global Civil Society says, "It's Simple: Start Abolition Negotiations Now!". RCW News in Review 20.

Calhoun C (2011) Civil society and the public sphere. Oxford University Press.

Calhoun CJ (1992) Introduction: Habermas and the Public Sphere. In: Calhoun CJ (ed.), Habermas and the public sphere, MIT press, pp. 1-50.

Carpenter C (2014) 'Lost' Causes: Agenda Vetting in Global Issue Networks and the Shaping of Human Security. Cornell University Press.

Carr M (2015) Power plays in global internet governance. Millennium 43(2): 640-659.

Carroll S (2002) NGO access to multilateral fora: does disarmament lag behind? In: NGOs as Partners: Assessing the Impact, Recognizing the Potential, UNIDIR Disarmament Forum.

Castells M (2008) The New Public Sphere: Global Civil Society, Communication Networks, and Global Governance. The ANNALS of the American Academy of Political and Social Science 616(1): 78-93.

Cohen JL and Arato A (1994) Civil society and political theory. MIT Press.

Conway J (2004) Citizenship in a time of empire: the World Social Forum as a new public space. Citizenship Studies 8(4): 367-381.

Conway J and Singh J (2009) Is the World Social Forum a Transnational Public Sphere?: Nancy Fraser, Critical Theory and the Containment of Radical Possibility. Theory, Culture \& Society 26(5): 6184.

Cornwall A (2002) Making spaces, changing places: situating participation in development.

Couldry N (2014) What and Where is the Transnationalized Public Sphere? In: Nash K (ed.), Transnationalizing the Public Sphere, Cambridge: Polity, pp. 43-59. 
Crack AM (2007) Transcending Borders? Reassessing Public Spheres in a Networked World. Globalizations 4(3): 341-354.

Dany C (2008) Civil society participation under most favourable conditions: Assessing the deliberative quality of the WSIS. Civil society participation in European and global governance, Houndmills: Palgrave Macmillan: 53-70.

Dany C (2012) Global Governance and NGO Participation: Shaping the information society in the United Nations. Routledge.

Deitelhoff N and Müller H (2005) Theoretical paradise-empirically lost? Arguing with Habermas. Review of international studies 31(01): 167-179.

Della Porta D (ed.) (2009) Another Europe: conceptions and practices of democracy in the European social forums. Routledge/ECPR studies in European political science, London ; New York: Routledge.

Della Porta D and Rucht D (2013) Meeting democracy: power and deliberation in global justice movements. Cambridge University Press.

Dryzek JS (2011) Global democratization: Soup, society, or system? Ethics \& International Affairs 25(02): 211-234.

Duarte S (2009) Bringing Democracy to Disarmament. In: Stockholm, Sweden: Swedish Network for Nuclear Disarmament.

Eckersley R (2007) A green public sphere in the WTO?: the amicus curiae interventions in the transatlantic biotech dispute. European Journal of International Relations 13(3): 329-356.

English J (1998) The Ottawa process: Paths followed, paths ahead. Australian Journal of International Affairs 52(2): 121-132.

Eriksen EO (2005) An Emerging European Public Sphere. European Journal of Social Theory 8(3): 341363.

Eriksen EO (2009) The unfinished democratization of Europe. Oxford University Press.

Falk R and Strauss AL (2011) A Global Parliament: Essays and Articles. Committee for a Democratic UN.

Fernandes S (2005) Transnationalism and Feminist Activism in Cuba: The Case of Magín. Politics \& Gender 1(03): 431-452.

Ferree MM, Gamson WA, Gerhards J, et al. (2002) Four models of the public sphere in modern democracies. Theory and society 31(3): 289-324.

Fihn B (2010) Implementing the vision should not be a bridge too far. RCW News in Review (12). 
Fihn B and Acheson R (2013) Moving towards a ban on nuclear weapons available on the Reaching Critical Will website http://www.reachingcriticalwill.org/disarmament-fora/hinw/oslo2013/conference-report

Fisher C (1999) Reformation and Resistance: Nongovernmental Organizations and the Future of Nuclear Weapons. Washington DC: The Henry L. Stimson Center.

Fisher DR (2010) COP-15 in Copenhagen: How the Merging of Movements Left Civil Society Out in the Cold. Global Environmental Politics 10(2): 11-17.

Fraser N (1992) Rethinking the Public Sphere: A Contribution to the Critique of Actually Existing Democracy. In: Calhoun CJ (ed.), Habermas and the public sphere, MIT press, pp. 109-142.

Fraser N (2008) Abnormal Justice. Critical Inquiry 34(3): 393-422.

Fraser N (2014) Transnationalizing the Public Sphere, On the Legitimacy and Efficacy of Public Opinion in a Post-Westphalian World. In: Nash K (ed.), Transnationalizing the Public Sphere, Cambridge: Polity.

Gandenberger M and Acheson R (2014) Highlights from the Conference. In: Acheson R (ed.), Filling the Gap: Report on the Third Conference on the Humanitarian Impact of Nuclear Weapons, New York: Reaching Critical Will, pp. 6-7.

Germain R (2010) Financial governance and transnational deliberative democracy. Review of International Studies 36(02): 493.

Gilman-Opalsky R (2008) Unbounded Publics: Transgressive Public Spheres, Zapatismo, and Political Theory. Lexington Books.

Habermas J (1991) The structural transformation of the public sphere: An inquiry into a category of bourgeois society. MIT press.

Habermas J (1996) Between facts and norms: contributions to a discourse theory of law and democracy. Studies in contemporary German social thought, Cambridge, Mass: MIT Press.

Hauser GA (1998) Civil society and the principle of the public sphere. Philosophy \& rhetoric 31(1): 19-40.

Helfer LR (2004) Regime shifting: the TRIPs agreement and new dynamics of international intellectual property lawmaking. Yale J. Int'I L. 29: 1.

Hopewell K (2017) Invisible Barricades: Civil Society and the Discourse of the WTO. Globalizations 14(1): 51-65.

Humphreys D (2008) NGO Influence on International Policy on Forest Conservation and the Trade in Forest Products. In: NGO Diplomacy: The Influence of Nongovernmental Organisations in International Environmental Negotiations, Cambridge, Mass: MIT Press, pp. 149-176.

ICAN (2010) Towards Nuclear Abolition: A Report by the International Campaign to Abolish Nuclear Weapons. ICAN. 
ICAN (2012) ICAN Campaign Meeting Report: Hiroshima ICAN Geneva

ICAN (2015) The Austrian Pledge: Stigmatize, prohibit and eliminate nuclear weapons. ICAN.

Interview (2015a) Director of International CSO affiliated to ICAN, Personal Interview, 23rd February 2015.

Interview (2015b) Member of the ICAN Board of Directors, Personal Interview, March 3rd 2015.

Interview (2015c) Staff member of ICAN, Personal Interview, 23rd February 2015.

Interview (2016a) Director of an International CSO affiliated to ICAN, 10th November 2016.

Interview (2016b) Research Director of an International CSO, Personal Interview, 6th November 2016.

Interview (2016c) Senior ICAN Campaigner, Personal Interview, 9th November 2016.

Johnson R (2010) NPT one week after consensus adoption of agreed document. Acronym Institute Blog.

Kaldor M (2007) Reply to David Chandler. Globalizations 4(2): 299-300.

Kapoor I (2004) Deliberative Democracy and the WTO. Review of International Political Economy 11(3): 522-541.

Kissling C (2013) Civil society and nuclear non-proliferation: how do states respond? Ashgate Publishing, Ltd.

Knopf J (2012) NGOs, Social Movements and Arms Control. In: Williams RE and Viotti PR (eds), Arms Control: History, Theory, and Policy, Santa Barbara: Praeger, pp. 169-194.

Kurasawa F (2014) An Alternative Transnational Public Sphere? On Anarchist Cosmopolitanism in PostWestphalian Times. In: Nash K (ed.), Transnationalizing the Public Sphere, Cambridge: Polity, pp. 79-97.

Lang S (2012) NGOs, civil society, and the public sphere. Cambridge University Press.

Lewis PM and Williams H (2013) The meaning of the Oslo Conference on the humanitarian impacts of nuclear weapons. In: Caughley T and Borrie J (eds), Viewing Nuclear Weapons through a Humanitarian Lens, Geneva: UNIDIR, pp. 145-157.

Loretz J (2009) Will the NPT finally open its arms to the Nuclear Weapons Convention. RCW News in Review 7.

Loretz J (2010) The Haas peace award: IPPNW's humanitarian message continues to resonate. IPPNW Peace and Health blog

Loretz J (2013) No boredom in Oslo: ICAN Civil Society Forum day 2 IPPNW Peace and Health Blog

Loretz J (2014) CSF Vienna-day two: the writing on the wall IPPNW Peace and Health Blog 
Løvold M, Fihn B and Nash T (2013) Humanitarian perspectives and the campaign for an international ban on nuclear weapons. In: Caughley T and Borrie J (eds), Viewing Nuclear Weapons through a Humanitarian Lens, Geneva: UNIDIR, pp. 145-157.

McCarthy T (1992) Practical Discourse: On the Relation of Morality to Politics. In: Calhoun CJ (ed.), Habermas and the public sphere, MIT press, pp. 51-72.

Minor E (2016) Disarmament, Development and Patterns of Marginalisation in International Forums. London (UK): Article36.

Montanaro L (2012) The democratic legitimacy of self-appointed representatives. The Journal of Politics 74(4): 1094-1107.

Muller H, Below A and Wisotzki S (2013) Beyond the State: Nongovernmental Organizations, the European Union, and the United Nations. In: Muller $\mathrm{H}$ and Wunderlich C (eds), Norm dynamics in multilateral arms control: interests, conflicts, and justice, University of Georgia Press, pp. 296336.

Nanz P and Steffek J (2004) Global governance, participation and the public sphere. Government and opposition 39(2): 314-335.

Nanz P and Steffek J (2005) Assessing the democratic quality of deliberation in international governance: criteria and research strategies. Acta politica 40(3): 368-383.

Nash K (2014) Towards Transnational Democratization? In: Nash K (ed.), Transnationalizing the Public Sphere, Cambridge: Polity, pp. 60-78.

Näsström S (2011) The Challenge of the All-Affected Principle. Political Studies 59(1): 116-134.

Nordstrom J (2007) Finding the Light. RCW News in Review (11): 1-2.

NPT (1994) Preparatory Committee for the 1995 Conference of the Parties to the Treaty on the NonProliferation of Nuclear Weapons. NPT/CONF.1995/PC.II/3.

NPT (2009a) Revised Draft Recommendations to the Review Conference. NPT/CONF.2010/PC.III/CRP.4/Rev.1.

NPT (2009b) Second Revised Draft Recommendations to the Review Conference. NPT/CONF.2010/PC.III/CRP.4/Rev.2.

NPT (2010a) Final Document (Volume 1). NPT/CONF.2010/50 (Vol.I).

NPT (2010b) Report of Main Committee I: Chairman's Draft on Substantive Elements. NPT/CONF.2010/MC.I/CRP.2.

NPT (2015a) statement by New Zealand on behalf of the New Agenda Coalition. 
NPT (2015b) Statement by Islamic Republic of Iran on behalf of the Group of Non-Aligned States Parties at the NPT Review Conference 1 May 2015

NPT (2015c) 2015 NPT Review Conference Joint Closing Statement As delivered by Austria.

NPT (2015d) Costa Rica's closing statement at the 2015 Review conference of the Non Proliferation Treaty.

NPT (2017) Statement by the Russian Federation at the Preparatory Committee for the 2020 Review Conference of the Parties to the Treaty on the Non-Proliferation of Nuclear Weapons.

Olesen T (2005) Transnational Publics: New Spaces of Social Movement Activism and the Problem of Global Long-Sightedness. Current Sociology 53(3): 419-440.

Orsini A (2013) Multi-Forum Non-State Actors: Navigating the Regime Complexes for Forestry and Genetic Resources Global Environmental Politics 13(3): 34-55.

Orsini A and Compagnon D (2013) From logics to procedures: arguing within international environmental negotiations. Critical Policy Studies 7(3): 273-291.

P5 (2013) P5 announcement not to attend the Oslo conference available on the Reaching Critical Will website at http://www.reachingcriticalwill.org/disarmament-fora/hinw/oslo-2013

Patomäki H and Teivainen T (2004) The World Social Forum. Theory, Culture \& Society 21: 6.

Peters B, Sifft S, Wimmel A, et al. (2005) 7 National and transnational public spheres: the case of the EU. European Review 13(5): 139-160.

Pieck SK (2013) Transnational Activist Networks: Mobilization between Emotion and Bureaucracy. Social Movement Studies 12(2): 121-137.

Porter T (2014) Constitutive public practices in a world of changing boundaries. In: Best J and Gheciu A (eds), The return of the public in global governance, New York: Cambridge University Press, pp. 223-242.

Price R (1998) Reversing the gun sights: transnational civil society targets land mines. International organization 52(3): 613-644.

Pytlak A and Acheson R (2017) States discuss rules for nuclear ban negotiations, Nuclear ban organisational meeting. Reaching Critical Will.

Risse T (2000) "Let's argue!": communicative action in world politics. International Organization 54(01): 1-39.

Risse T (2015) A community of Europeans?: transnational identities and public spheres. Cornell University Press. 
Rucht D (2012) Social forums as public stage and infrastructure of global justice movements. In: Smith J, Byrd S, Reese E, et al. (eds), Handbook on World Social Forum Activism, Boulder: Paradigm, pp. 11-28.

Samhat N and Payne R (2003) Regimes, Public Spheres and Global Democracy: Towards the Transformation of Political Community. Global Society 17(3): 273-295.

Sauer T (2015) The NPT and the Humanitarian Initiative: Towards and Beyond the 2015 NPT Review Conference. Deep Cuts Working Paper.

Saward M (2008) Representation and Democracy: Revisions and Possibilities. Sociology Compass 2(3): 1000-1013.

Scholte JA (2012) A More Inclusive Global Governance? The IMF and Civil Society in Africa. Global Governance: A Review of Multilateralism and International Organizations 18(2): 185-206.

Smith W (2011) Civil disobedience and the public sphere. Journal of Political Philosophy 19(2): 145-166.

Steffek J (2010) Public Accountability and the Public Sphere of International Governance. Ethics \& International Affairs 24(1): 45-68.

Steffek J, Kissling C and Nanz P (2007) Civil society participation in European and global governance: A cure for the democratic deficit? Springer

Steffek J, Bendrath R, Dalferth S, et al. (2010) Assessing the democratic legitimacy of transnational CSOs: five criteria. In: Steffek J and Hahn K (eds), Evaluating Transnational NGOs: Legitimacy, accountability, representation, Springer, pp. 100-125.

Stevenson H and Dryzek JS (2012) The discursive democratisation of global climate governance. Environmental Politics 21(2): 189-210.

Stevenson H and Dryzek JS (2014) Democratizing global climate governance. Cambridge University Press.

Stone D (2002) Introduction: global knowledge and advocacy networks. Global networks 2(1): 1-12.

Tarrow S (2005) The dualities of transnational contention:" Two activist solitudes" or a new world altogether? Mobilization: An International Quarterly 10(1): 53-72.

Tännsjö T (2008) Global democracy: The case for a world government. Edinburgh University Press.

Thakur R, Boulden J and Weiss TG (2008) Can the NPT regime be fixed or should it be abandoned? Berlin; Geneva; New York, NY: Friedrich-Ebert-Stiftung.

Trenz H-J (2008) In Search of the European Public Sphere: between normative overstretch and empirical disenchantment. Arena.

United Nations General Assembly (UNGA) (2016) Report of the Open-ended Working Group taking forward multilateral nuclear disarmament negotiations. 
Velin J-A (1997) Stage Three Of The Ottawa Process: The Oslo Diplomatic Conference. Disarmament Diplomacy (18).

Volkmer I (2014) The global public sphere: Public communication in the age of reflective interdependence. John Wiley \& Sons.

Walker W (2011) A perpetual menace: Nuclear weapons and international order. Routledge

Williams H, Lewis PM and Aghlani S (2015) The Humanitarian Impacts of Nuclear Weapons Initiative: The 'Big Tent' in Disarmament. International Security, London (UK): Chatham House.

Wisotzki S (2009) Negotiating human security at the UN: Transnational civil society, arms control and disarmament in Joachim et al Transnational Activism pp74-87

Wright T (2007) Hiroshima's mayor launches anti-nuclear campaign. RCW News in Review 2.

Wright T (2010) Growing support for a nuclear weapons convention. RCW News in Review 1.

Yanacopulos H (2015) International NGO Engagement, Advocacy, Activism: The Faces and Spaces of Change. Springer.

Young IM (2002) Inclusion and democracy. Oxford University Press 